\title{
English Teachers Assess Instructional Methods Supporting Knowledge Processes
}

\author{
Andreas Zendler \\ Department of Computer Science, University of Education Ludwigsburg \\ Reuteallee 46, 71634 Ludwigsburg, Germany \\ Tel: ++49 (0)7141-140-683Ｅ-mail: zendler@ ph-ludwigsburg.de
}

Received: January 22, 2018 Accepted: February 1, 2018 Published: February 2, 2018

doi:10.5296/ijele.v6i1.12580 URL: https://doi.org/10.5296/ijele.v6i1.12580

\begin{abstract}
Answers to the questions of which instructional methods are suitable for school, which instructional methods should be applied in teaching individual subjects and how instructional methods support the act of learning represent challenges to general education and education in individual subjects. This article focuses on the empirical examination of instructional methods supporting knowledge processes in the act of learning. A survey was conducted in which English teachers evaluated 20 instructional methods in regard to the following knowledge processes: build, process, apply, transfer, assess and integrate. The results of the study demonstrate that certain instructional methods are especially predestined for the English classroom: project work, jigsaw, problem-based learning, learning tasks, learning stations, presentation, learning by teaching, discovery learning, and role-play.
\end{abstract}

Keywords: English classroom, instructional methods, teaching tools, knowledge processes, act of learning 


\section{Introduction}

The wide range of instructional methods is almost incomprehensible. The associated literature describes a broad spectrum of instructional methods ranging from methods of conveying and acquiring knowledge to management methods for games, movement, emotions, groups, health, violence and conflicts. Gugel (2011) cites more than 2,000 methods including their variations. The Internet provides well-prepared monographs of instructional methods, e.g. The Center for Teaching and Learning (2018) cites 150 instructional methods. For English classroom a number of good standard reference work is available which addresses the application of instructional methods (e.g. Grieser-Kindel, Henseler, \& Möller, 2006; Müller-Hartmann \& Schocker-von-Ditfurth, 2011; Scrivener, 2011; Timm, 2005).

Meyer (2002) is a source of a very general definition stating that instructional methods are the forms and procedures with which teachers and school pupils perceive the natural and social reality surrounding them while observing the institutional framework conditions of the school. A stricter definition of method (than the one formulated above) which also represents the conceptual starting point for this article comes from Huber and Hader-Popp (2007): "The word method is understood to mean a clearly defined, conceptually perceivable and independent, if also integrated, component of teaching." (Huber \& Hader-Popp, 2007, p. 3).

Hattie (2009, chapter 9 and 10) informs about empirical results on the effectiveness of teaching methods in general. High effect sizes $(d>.50)$ were demonstrated for microteaching $(d=.88)$, reciprocal teaching $(d=.74)$, feedback $(d=.73)$, problem solving $(d=.61)$, direct instruction $(d=.59)$, mastery learning $(d=.58)$, case study $(d=.57)$, concept mapping $(d$ $=.57)$, peer tutoring $(d=.55)$, cooperative (vs. competitive) learning $(d=.54)$, and interactive instructional videos $(d=.52)$. The empirical results presented by Hattie are kept very general and cannot be concretized for individual subjects. Particularly, for English classroom empirical findings are lacking on the effectiveness of instructional methods with respect to the act of learning.

The search through magazines and conference reports on English classroom research shows that empirical studies on the effectiveness of instructional methods are rare. Current work provided findings related ${ }^{1}$ to task oriented instructional methods (Ökcü, 2014; Seyedi, \& Farahani, 2014), instructional methods with written feedback (Heffernan, Otoshi, \& Kaneko; Dehghani, Sadighi, \& Seyari, 2015) as well as computer-based programs in English classroom (Dehghani, Sadighi, \& Seyari, 2014; Hassan, \& Ahamed, 2016).

However, a variety of teaching examples with methodical focus are included in practice-oriented journals on English classroom, e.g. Unterricht Englisch, Lehrer-online, At work Magazin. Zendler, Seitz and Klaudt (2016) describe implementation steps for 20

International Journal of English Language Education, International Journal of English and Education, The Journal of English as an International Language, International Journal of English Language Teaching, The Journal of English Language Teaching and Learning, English Education, English Language Teaching 
different instructional methods (see Appendix 1. Instructional Methods) and specify references which exemplify the instructional methods in English classroom.

Many theoretical learning/teaching approaches make a distinction between phases/processes/cycles for which instructional methodology aids are formulated; overviews of such are provided by Tennyson et al. (1997) and Petrina (2006). For instance, Merill (2002) suggests that the most effective learning environments are those that are problem-based and involve the student in four distinct phases of learning: (1) activation of prior experience, (2) demonstration of skills, (3) application of skills, and (4) integration of these skills into real world activities.

The theory from Collins, Brown and Newman (1989), which has situated learning at its core, reveals four main phases: modeling, scaffolding, fading, and coaching. Cognitive oriented approaches (Bruner, 1966; Gagné et al., 2004) link instruction to the acquisition and processing of knowledge. They emphasize three (cognitive/knowledge) processes in the act of learning: acquisition of new information, transformation (manipulating knowledge to make it fit new tasks), evaluation (checking whether the way we have manipulated information is adequate to the task) (see Bruner, 1966, p. 48; Merriam \& Caffarella, 2006, p. 46; Gowda, 2010).

A robust theory to instructional methods for English classroom is missing, which should answers to the questions: (1) which instructional methods should be used to teach English, (2) in which kind of way do teaching methods support the learning process in English education, and (3) which instructional methods are particularly suitable for which English learning objects.

In view of the fact that there is little empirical material to date on instructional methods in English classroom, three objectives have been at the forefront of the interest of a research project at the University of Education Ludwigsburg: (1) An inventory of English classroom instructional methods: What instructional methods are currently in use in English classroom?, (2) instructional methods for the subject of English classroom: Which instructional methods are appropriate for English classroom?, and (3) specific application of instructional methods for the subject of English classroom: To what degree do instructional methods support the act of learning in English classroom?

The following research hypothesis is linked with these three objectives: "Instructional methods for the subject of English classroom differ in supporting the act of learning".

This article is structured as follows: The content in section 2 consists of the (research) methods applied, describing the study design and procedures as well as the data analysis strategy. Then, we give a detailed account of our findings. In the last section we discuss the findings and, finally, draw implications. 


\section{Method}

\subsection{Research design}

Selection of instructional methods. The review of a series of instructional methods manuals (Ginnis 2001; Petrina 2006; Davis 2009; Joyce \& Weil 2008; Peterßen 2009; Petty 2009; Brenner \& Brenner 2011; Wiechmann 2011; Cruickshank et al. 2011) revealed more than 50 instructional methods to choose from. The review was characterized by the requirement that instructional methods had to pass the muster as being capable of being understood as clearly defined, conceptually perceivable and independent components of the instruction.

The following criteria were applied for the final selection of the instructional methods: (1) The actual application of the instructional methods in English classroom and (2) empirically examined instructional methods. The following 20 instructional methods (in alphabetical order) were able to be selected on the basis of these criteria.

Case study, computer simulation, concept mapping, direct instruction, discovery learning, experiment, jigsaw method, learning at stations, learning by teaching, learning tasks, Leittext method, models method, portfolio method, presentation, problem-based learning, programmed instruction, project work, reciprocal teaching, role-play, and web quest (see Appendix 1. Instructional Methods).

Processes involved in the act of learning. The educational literature knows numerous variations relating teaching to learning as an act spread over time and to phases which can be distinguished during the course of learning (Bruner 1966; Petrina 2006; Olson 2007; Davis 2009). What all of the variations have in common is that learning (1) has a starting point, (2) a sequential form and (3) a (generally preliminary) end point. Educational literature describes this as the classic three-step pattern divided into the steps labeled entry, work phase and graduation. These three steps have particularly large distinctions in their educational functions and in the knowledge processes of the act of learning. Particularly in the work phase, important knowledge processes (Bruner 1966; Merriam \& Caffarella, 2006; Gowda 2010) can be distinguished in the act of learning. This indicates the processes in the acquisition of knowledge (build, process), in the transformation of knowledge (apply, transfer) and in the evaluation of knowledge (assess, integrate) (see Appendix 2. Knowledge Processes).

Experimental design. An RBF-20×6 experimental design (Randomized Block Factorial design, 2-factor design with repeated measures, see Figure 1) is used to test the research hypothesis (Winer, Brown, \& Michels, 1991; Kirk 2012).

Independent variables. Factor $A$ comprises the $p=20$ instructional methods with factor levels $a_{1}, \ldots, a_{20}$ : case study, computer simulation, concept mapping, direct instruction, discovery learning, experiment, jigsaw method, learning at stations, learning by teaching, learning tasks, Leittext method, portfolio method, presentation, problem-based learning, programmed instruction, project work, reciprocal teaching, role-play, and web quest. Factor $B$ represents the $q=6$ knowledge processes with factor levels $b_{1}, \ldots, b_{6}$ : build, process, apply, transfer, assess and integrate. 


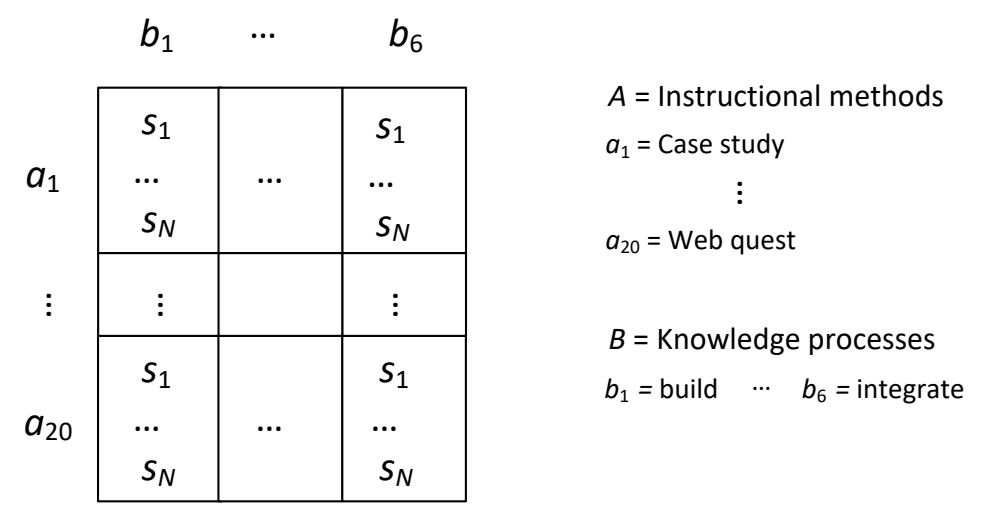

Figure 1. Layout of the used RBF-20×6 experimental design

Dependent variable. The dependent variable was the respondents' evaluation of the instructional methods with respect to the six knowledge processes. Ratings were given on a six-point scale with ratings ranging from 0 ("not significant") to 5 ("very significant").

Power analysis. The sample size for the RBF- $20 \times 6$ experimental design (Mueller \& Barton 1989; Mueller et al. 1992) is determined with a type II power analysis $-N$ as a function of power $(1-\beta), \Delta$ and $\alpha$. The desired power $(1-\beta)$ is 0.80 , and only large effects $(\Delta=0.80)$ in relation to the dependent variable are classified as significant; the significance level is $\alpha=0.05$. Then a total sample of approximately $N^{*}=120$ English teachers is needed, based on the power calculations by Mueller and Barton (1989), respectively, by Mueller, LaVange, Ramey and Ramey (1992) for $\varepsilon$-corrected $F$-Tests.

"Instructional methods for the English classroom differ in supporting the act of learning, as operationalized by English teachers' ratings on a six-point scale of the knowledge processes build, process, apply, transfer, assess, and integrate."

\subsection{Procedure}

Sample. For the empirical study, a total of 120 English teachers working at secondary schools in the German State of Baden-Württemberg were contacted in writing and asked to fill out a questionnaire on the application of instructional methods in English classroom. The English teachers who completed and returned the questionnaire taught English in the grade levels 5 through 12/13 [grade 5-7 $(n=25)$, grade 8-10, $(n=22)$, and grade 11-12/13 $(n=25)$ ]. On average they had taught English for more than 9 years; in addition to teaching English, the teachers taught German $(n=10)$, an additional foreign language $(n=8)$, and history $(n=7)$.

Questionnaire. The questionnaire consisted of a short introduction listing the 20 instructional methods and the 6 knowledge processes. The questionnaire was accompanied by a booklet (Zendler, Seitz, \& Klaudt, 2016) for the English teachers describing the 20 instructional methods in accordance with a uniform scheme containing (1) a brief description and 


\section{Ml Macrothink}

explanation, (2) concrete execution steps, and (3) examples from the relevant literature verifying the application of the instructional method in English classroom.

Tasks. The $p=20$ instructional methods and the $q=6$ knowledge processes were then presented in alphabetical order in a matrix with the instructional methods in rows and the knowledge processes in columns. Participants were asked to indicate the relevance of each of the $20 \times 6=120$ matrix cells: Each cell represents a combination of an instructional method and a knowledge process and requires an integer from 0 ("not significant") to 5 ("very significant") indicating the relevance of the combination (see Appendix 3. Questionnaire).

Return rate. To maximize the return rate, we mailed the questionnaire in sealed, personalized envelopes enclosing a pre-addressed return envelope franked with stamps showing flower designs (see Dillman, 2000 for recommendations on increasing return rates). The return rate was $23.3 \%$ ( $N=28$ completed questionnaires of 31 received questionnaires), which can be regarded as a normal rate for surveys conducted by post (cf. Vaux \& Briggs, 2005).

\subsection{Data Analysis}

The following procedure is recommended for the analysis of the experimental data (original data, see Appendix 4. Data): (1) The data are initially analyzed descriptively. (2) Then a two-factor analysis of variance (ANOVA) with repeated measures was conducted in accordance with the RBF-20×6 experimental design (see Winer et al. 1991, Chapter 7). (3) Finally, a cluster analysis is calculated aimed at identifying groups of instructional methods which can be characterized by their support of similar knowledge processes in the act of learning.

The data on the RBF- $20 \times 6$ experimental design were analyzed using IBM SPSS Statistics 23.0; the power analysis was calculated using PASS 13.

\section{Results}

\subsection{Descriptive Findings}

The heat map seen in Figure 2 contains means visualized for the 20 instructional methods in relation to the six cognitive/knowledge processes processes: build, process, apply, transfer, assess, and integrate. The figure also contains the grand means $(N=28)$ per instructional method. The instructional methods are sorted in accordance with these grand means. 


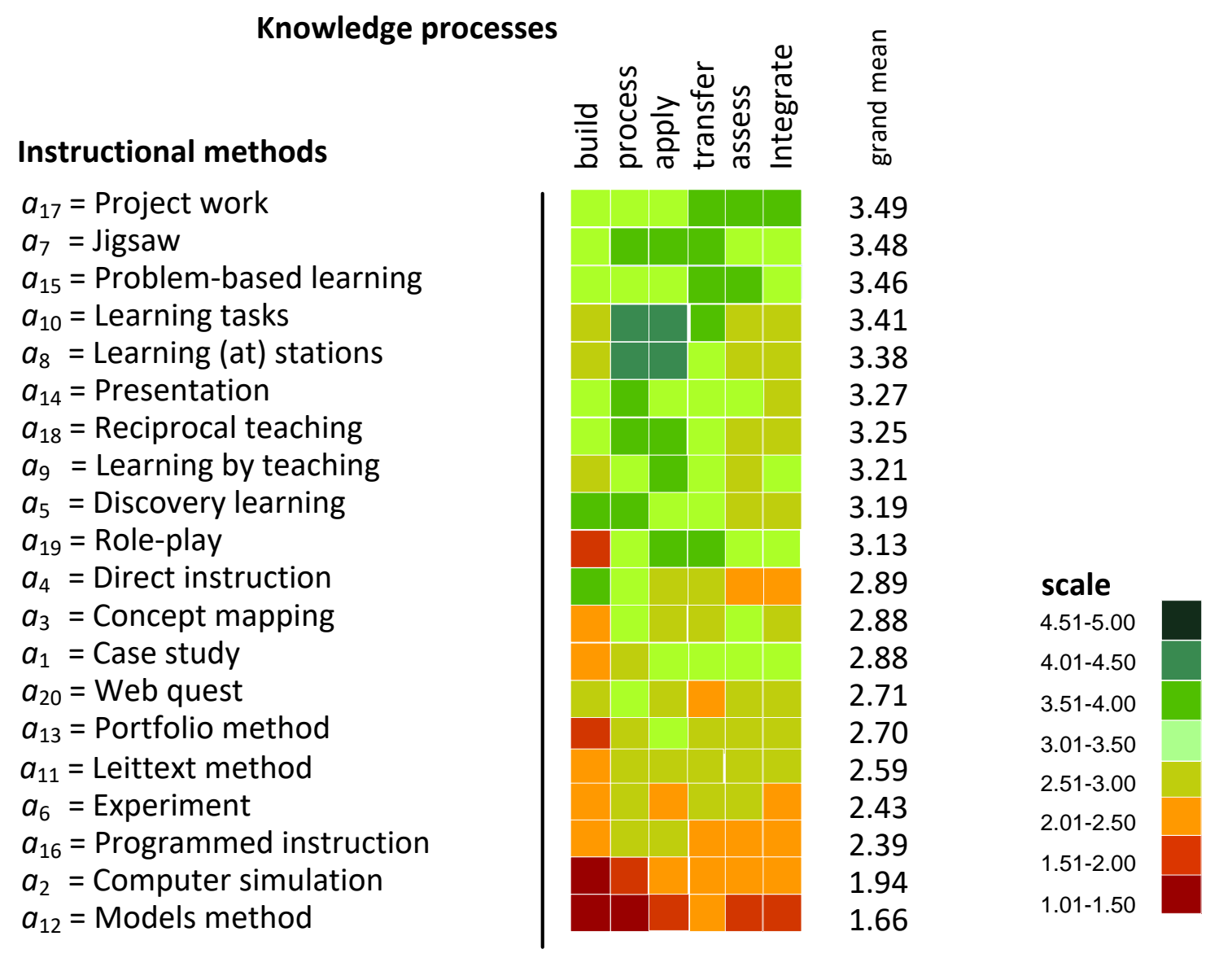

Figure 2. Means visualized for the cognitive/knowledge processes

Figure 1 shows initially that project work, jigsaw, problem-based learning were assessed by the English teachers as best methods for supporting the act of learning in English classroom; these methods are followed by six additional instructional methods: learning tasks, learning stations, presentation, reciprocal teaching, learning by teaching, discovery learning, and role-play.

In a more detailed observation the heat map reveals that project work, jigsaw, and problem-based learning are distinguished by high values (> 3.00) for the knowledge processes. The instructional methods learning task and learning stations show relatively high values for the knowledge processes of process and apply. The discovery learning instructional method demonstrates high values for the knowledge processes build and process. The role-play instructional method is noteworthy, because it is characterized by relatively low values for the knowledge process build on the one hand, and, on the other hand, by relatively high values for the knowledge processes of process and apply. The following instructional methods have relatively low values in almost all knowledge processes: Leittext method, experiment, and programmed instruction. Computer simulation and the models method have been assessed relatively poor $(<2.50)$ in all knowledge processes. 


\subsection{Analysis of Variance}

To examine whether the combinations of instructional methods and knowledge processes within the act of learning differ, three statistical hypotheses are formulated which are tested at the significance level of $\alpha=0.05$.

Statistical hypotheses. The three null hypotheses are as follows:

i) the means of the instructional methods $\mu_{1}, \mu_{2}, \ldots, \mu_{20}$ under the 20 levels of factor $A$ are equal, i.e.:

$$
H_{0}: \mu_{1}=\mu_{2}=\ldots=\mu_{20} \quad\left(H_{1}: \mu_{1} \neq \mu_{2} \neq \ldots \neq \mu_{20}\right) ;
$$

ii) the means of the knowledge processes in the act of learning $\mu_{1}, \mu_{2}, \ldots, \mu_{6}$ under the 6 levels of factor $B$ are equal, i.e.:

$$
H_{0}: \mu_{1}=\mu_{2}=\ldots=\mu_{6} \quad\left(H_{1}: \mu_{1} \neq \mu_{2} \neq \ldots \neq \mu_{6}\right) ;
$$

iii) the means of the instructional methods with respect to the knowledge processes $\mu_{1 \times 1}, \mu_{1 \times 2}, \ldots, \mu_{20 \times 6}$ under the $20 \times 6$ levels of the factor combinations $A \times B$ are equal, i.e.:

$$
H_{0}: \mu_{1 \times 1}=\mu_{1 \times 2}=\ldots=\mu_{20 \times 6} \quad\left(H_{1}: \mu_{1 \times 1} \neq \mu_{1 \times 2} \neq \ldots \neq \mu_{20 \times 6}\right) .
$$

Testing the statistical assumptions. For an analysis of variance of an RBF-20×6 experimental design, the data must satisfy the condition of sphericity. This assumption was tested using Mauchly's $W$ test for sphericity, with the test statistic $W$ being compared to a chi-square distribution to assess the adequacy of the sphericity.

The assumption of sphericity must be discarded both for the instructional methods $\left(W<0.001, \chi^{2}{ }_{189}=339.02, p<0.001\right)$ and also for the processes of the acquisition of knowledge $\left(W=0.116, \chi_{14}^{2}=70.60, p<0.001\right)$ at the $\alpha$-level of 0.05 . In the further analysis, we therefore applied the $\varepsilon$-correction of degrees of freedom proposed by Huynh and Feldt (1976).

Findings. Table 1 contains the results of the ANOVA with the $\varepsilon$-correction of the degrees of

\begin{tabular}{|c|c|c|c|c|c|c|}
\hline Source of variation (within) & $S S$ & $d f$ & $M S$ & $\boldsymbol{F}$ & $p$ & $\eta 2$ \\
\hline A (instructional methods) & 855.81 & 11 & 78.91 & 6.57 & $<.001$ & .196 \\
\hline error (A) & 3513.46 & 293 & 12.00 & & & \\
\hline$B$ (knowledge processes) & 162.27 & 3 & 59.21 & 7.88 & $<.001$ & .226 \\
\hline $\operatorname{error}(B)$ & 555.80 & 74 & 7.51 & & & \\
\hline$A \times B$ & 313.16 & 28 & 11.05 & 3.11 & $<.001$ & .103 \\
\hline $\operatorname{error}(A \times B)$ & 2723.30 & 765 & 3.56 & & & \\
\hline
\end{tabular}
freedom.

Table 1. ANOVA with Huynh-Feldt $\varepsilon$-corrections of the degrees of freedom 


\section{Ml Macrothink}

The main effect $A$ (instructional methods) is significant $\left(F_{11,293}=6.57, p<0.001\right)$ at the $\alpha$-level of 0.05 , i.e., the corresponding $H_{0}$ is rejected: the instructional methods differ from one another.

The main effect $B$ (knowledge processes) is significant $\left(F_{3,74}=7.88, p<0.001\right)$ at the $\alpha$-level of 0.05 , i.e., the corresponding $H_{0}$ is rejected: the knowledge processes differ from one another.

The interaction effect $A \times B$ (instructional methods $\times$ knowledge processes) is significant $\left(F_{28765}=3.11, p<0.001\right)$ at the $\alpha$-level of 0.05 , i.e., the corresponding $H_{0}$ is rejected: the instructional methods differ from one another with respect to knowledge processes.

\subsection{Cluster Analysis}

The alphabetically sorted $20 \times 6$ data matrix (see Appendix 4. Data) with the means of the instructional methods in regard to the knowledge processes is taken as the data basis for the cluster analysis. The cluster analysis has been done using the method of Ward (1963) with squared Euclidean distance as distance measure (Everitt et al., 2001). For the termination of the algorithm, the C-Index (Hubert \& Levin, 1976) has been taken into consideration (this is visualized as "cut" in the following figure 3 ).

Figure 3 shows the results of the cluster analysis for the instructional methods. The dendrogram reveals that five clusters with instructional methods emerged. Cluster 1, 2, and 3 contain instructional methods with (relatively) high values for many knowledge processes. Cluster 4 and 5 contain instructional methods with (relatively) low values for many knowledge processes.

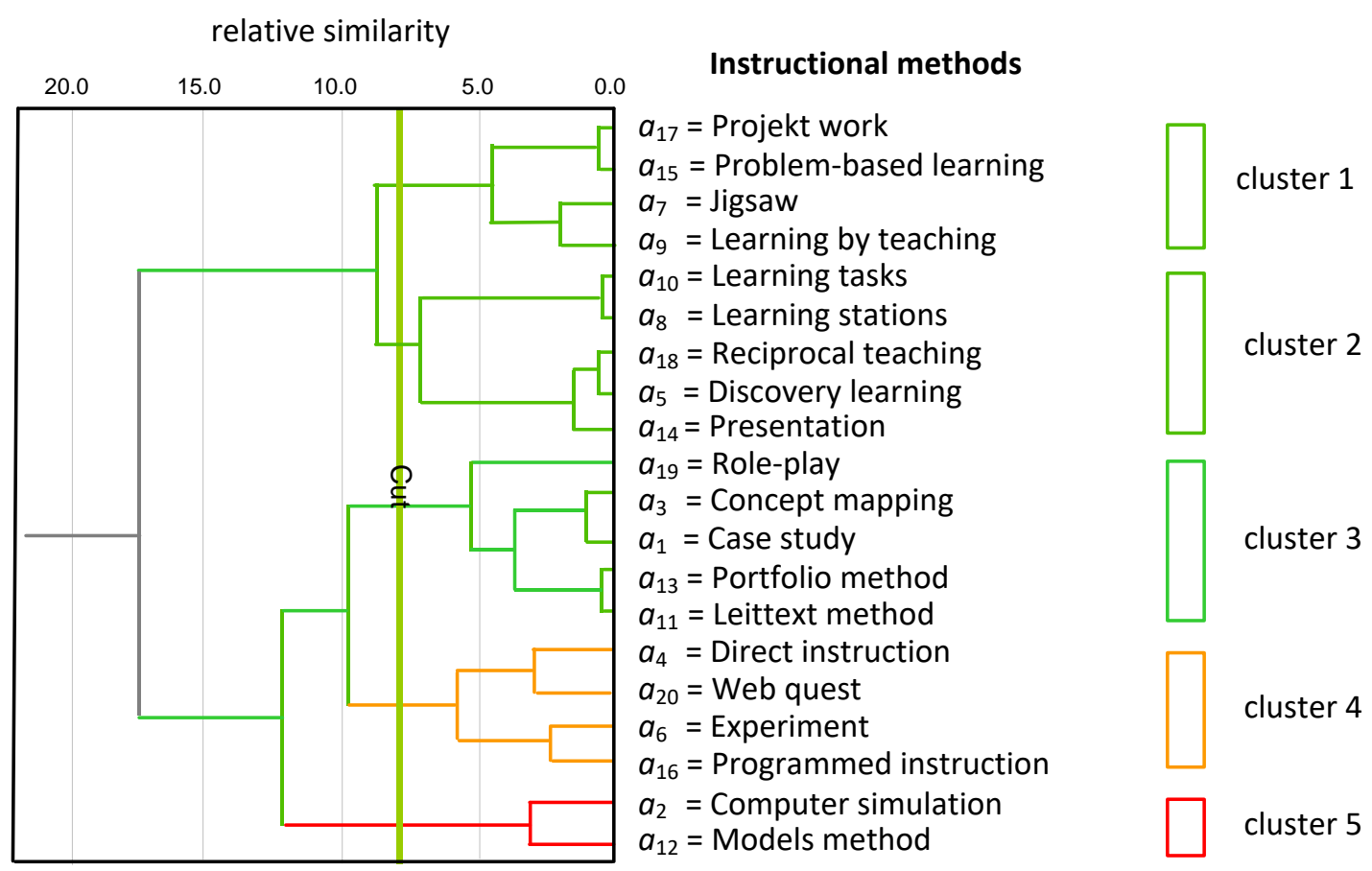

Figure 3. Dendrogram and clusters of instructional methods $(N=28)$ 
Cluster 1. This cluster contains the four instructional methods project work, problem-based learning, jigsaw, and learning by teaching. They are characterized by similarily high values for the knowledge transfer. Considering the dendrogram and the heatmap it is obvious that this cluster cannot be merged with other instructional methods due to the value for the C-index (see "Cut" in Figure 3).

Cluster 2. This cluster consists of the five instructional methods learning tasks, learning stations, reciprocal teaching, discovery learning, and presentation. These methods are characterized by values that are similarily high in regard to the knowledge processes of process, apply, and transfer (see the data in Appendix 4. Data).

Cluster 3. This cluster consists of the following five instructional methods: role-play, concept-mapping, case study, portfolio method, and the Leittext method. These methods are characterized by some high values for individual knowledge processes. Noteworthy is case study, it is characterized by relatively high values for the knowledge processes apply, transfer, assess, and integrate.

Cluster 4. This cluster consists of four instructional methods: Direct instruction, web quest, experiment, and programmed instruction. They are characterized by relatively low values for most of the knowledge processes.

Cluster 5. This cluster contains the two instructional methods computer simulation and models method. They are characterized by low values for almost all knowledge processes (see the data in Appendix 4. Data).

\section{Discussion}

First, it must be noted that the findings support the research hypothesis formulated in this paper's Introduction that instructional methods for English classroom differ in supporting the act of learning.

In the opinions of the English teachers, project work, jigsaw and problem-based learning seem to perform best in relation to almost all of the knowledge processes. Discovery learning and direct instruction are best suited for the knowledge processes of build. Learning tasks and learning stations are the instructional methods that are suitable for the knowledge processes of process and apply. The instructional models reciprocal learning and learning by teaching method can be used with respect to the knowledge process of apply. The instructional methods that are unsuitable for English classroom are computer simulation and the models method.

Additionally, these findings also answer the question regarding which knowledge processes are adequately supported by which instructional method. It must first be noted that the knowledge processes in the act of learning are supported by the instructional methods in wholly different ways. The knowledge process build is supported by the instructional methods discovery learning and direct instruction. The situation is similar for the knowledge process of process which is positively influenced by the instructional methods jigsaw, 
learning tasks, learning stations, presentation, reciprocal teaching, and discovery learning. The knowledge processes apply is supported in particular when the instructional methods jigsaw, learning tasks, learning stations, reciprocal teaching, learning by teaching, and role-play are applied. The knowledge processes transfer is supported when the instructional methods project work, jigsaw, problem-based learning, learning tasks, and role-play are used. The knowledge processes assess and integrate are supported by two instructional methods, namely project work and problem-based learning. Only project work remains for the knowledge process integrate.

The first three knowledge processes (build, process, apply) receive significantly greater support from the instructional methods than the last three knowledge processes (transfer, assess, integrate). The knowledge process assess is only relatively well supported by two instructional methods (project work, problem-based learning,), while the knowledge process integrate is only supported by one instructional method (project work).

The following recommendations can be expressed for the application of instructional methods in English classrooms: (1) For building knowledge direct instruction should be used in combination with discovery learning and augmented by learning tasks in order to initiate the knowledge process of process. (2) For the knowledge process of apply, learning tasks should be used in combination with other instructional methods such as jigsaw, learning stations, and learning by teaching. (3) To support the knowledge processes of transfer, assess, and integrate, project work should be used and supported by problem-based learning. (4) To introduce diversity into English classroom and to increase the motivation of the learners it is recommended to use instructional methods in a substituting role to the extent that they support similar knowledge processes. It can for instance be derived from the heat map that learning tasks and learning stations are similar in their relation to the knowledge processes of process and apply, as are project work, jigsaw, problem-based learning, learning tasks, and role-play for the knowledge process of transfer.

The findings determined in this examination on the application of instructional methods to teach English confirm the recommendations made in standard works on the subject of in English classroom. This applies for the instructional methods discovery learning, learning by teaching, learning tasks, role-play, project work, presentation, reciprocal teaching, station learning (cf. Timm, 2005; Grieser-Kindel, Henseler, \& Möller, 2006; Thaler, 2012; Müller-Hartmann \& Schocker-von-Ditfurth, 2011; Scrivener, 2011).

The data from English teachers who teach at secondary schools were included in the study. In order to verify and validate the results of these findings an examination should take place in authentic teaching and learning settings, and should not be based on subjective opinions. Instructional methods assessed in this study as being very unfavorable for English classroom such as computer simulation and models method do not need to be observed further.

Moreover, the findings in this study showed that the knowledge processes assess and integrate are only adequately supported by two instructional method, namely project work and problem-based learning. As such, the field of developing methods for English classroom is faced with the task of developing instructional methods which support these knowledge 


\section{Macrothink}

processes in the act of learning. In the authors' opinion, the starting point for the development of such instructional methods can be found within the context of competence-based learning tasks and in cross-curricular instruction.

\section{Acknowledgments}

We thank Natascha Treter for her support with preparing the survey. The project was funded by University of Education Ludwigsburg.

\section{References}

Abell, S. K., \& Lederman, N. G. (2007). Handbook of research on science education. New York: Lawrence Erlbaum.

Aldrich, C. (2009). Simulations \& serios games. San Francisco: Pfeiffer.

Aronson, E. (1978). The jigsaw classroom. Beverly Hills: Sage Publications.

Branom, M. E. (1918). The project method in education. London: BiblioBazaar (Reprinted 2008).

Brenner, G., \& Brenner, K. (2011). Methoden für alle Fälle. Berlin: Cornelsen.

Bruner, J. S. (1966). The process of education. Cambridge: Harvard University Press.

Canton, R. K. (2007). Programmed Instruction in online learning. Boston: Cambia Press.

Collins, A., Brown, \& Newman, S. E. (1989). Cognitive apprenticeship. Teaching the crafts of reading, writing, and mathematics. In L. B. Resnick (Ed.), Knowing, learning and instruction (pp. 453-494). Hillsdale: Erlbaum.

Cruickshank, D. R., Jenkins, D. B., \& Metcalf, K. K. (2011). The act of teaching. Boston: McGraw Hill.

Davis, Gross B. (2009). Tools for teaching. San Francisco: Jossey-Bass.

Dehghani, A. P., Sadighi, F., \& Seyari, A. (2014). The effect of computer-based programs on Iranian EFL Learners' knowledge of Grammar through Writing. International Journal of English and Education, 4(1), 88-99.

Dehghani, A. P., Sadighi, F., \& Seyari, A. (2015). Comparative study of the effectiveness of direct feedback and indirect feedback methods for Urdu EFL learners' writing. International Journal of English and Education, 4(2), 225-240.

Dillman, D. A. (2000). Mail and Internet surveys: the tailored design method. New York: Wiley.

Donath, R. (2006). Portfolio-Praxis im Leistungskurs Englisch - school reality sometimes bytes. In W. Gehring (Ed.), Fremdsprachenunterricht heute (57-66). Oldenbourg: BIS 
Everitt, B. S., Landau, S., \& Leese, M. (2001). Cluster analysis. London: Arnold.

Flewelling, G., \& Higginson, W. (2003). Teaching with rich learning tasks: A handbook. Sydney: Australian Association of Mathematics Teachers.

Gagne, R. M., Wagner, W. W., Golas, K., \& Keller, J. M. (2004). Principles of instructional design. London. Wadsworth Publishing.

Gartner, A., Kohler, M. C., \& Riessman, F. (1971). Children teach children. Learning by teaching. New York: Harper \& Row.

Ginnis, P. (2001). The teacher's toolkit. Classroom achievement. Carmarthen: Crown House Publishing.

Gowda, N. S. (2010). Learning and the learner: Insights into the processes of learning and teaching. Delhi: PHI Learning.

Grieser-Kindel, C., Henseler, R., \& Möller, S. (2006). Method guide (5-10). Paderborn: Schöningh.

Grieser-Kindel, C., Henseler, R., \& Möller, S. (2009). Method guide (5-12). Paderborn: Schöningh.

Gugel, G. (2011). 2000 Methoden für Schule und Lehrebildung. Weinheim: Beltz.

Hassan I. O., \& Ahamed H. H. (2016). The Impact of instructional technologies in teaching English in Sudanese secondary schools in Khartoum state. International Journal of English Language Teaching, 4(1), 56-63.

Hattie, J. (2009). Visible learning. New York: Routledge.

Heffernan, N., Otoshi, J., \& Kaneko, Y. (2014). Written feedback in Japanese EFL classrooms: A focus on content and organization. Journal of English Language Teaching and Learning, 4(1), 55-68.

Höpfner, H.-D., Koch, J., Meerten, E., Rottluff, J., Schneider, P. J., \& Selka, R. (1997). Leittext - the self-reliant way of learning. Bielefeld: Bertelsmann.

Huber, S. G., \& Hader-Popp, S. (2007). Unterrichtsentwicklung durch Methodenvielfalt im Unterricht fördern: das Methodenatelier als schulinterne Fortbildung. In A. Bartz, J. Fabian, S. G. Huber, Kloft, C. H. Rosenbusch, H. Sassenscheidt (Eds.), PraxisWissen Schulleitung (30.31). München: Wolters Kluwer

Hubert, L. J., \& Levin, J. R. (1976). A general statistical framework for assessing categorical clustering in free recall. Psychological Bulletin 83, 1072-1080.

Huynh, H., \& Feldt, L. S. (1976) Estimation of the Box correction for degrees of freedom from sample data in randomised block and split-plot designs. Journal of Educational Statistics, 1, 69-82.

Joyce, B. R., \& Weil, M. (2008). Models of teaching. New York: Prentice-Hall. 
Kirk, E. (2012). Experimental design. Belmont: Wadsworth.

Merill, M. D. (2002). First principles. Educational Technology Research and Development, $50(3), 43-59$.

Merriam, S. B., \& Caffarella, R. S. (2006). Learning in adulthood: A comprehensive guide. New York: Jossey Bass.

Meyer, H. (2002). Unterrichtsmethoden. In H. Kiper, H. Meyer, \& W. Topsch (Eds.), Einführung in die Schulpädagogik (pp. 109-121). Berlin: Cornelsen.

Mueller, K. E., \& Barton, C. N. (1989). Approximate power for repeated-measures ANOVA lacking sphericity. Journal of the American Statistical Association, 84(406), 549-555.

Mueller, K. E., LaVange, L. E., Ramey, S. L., \& Ramey, C. T. (1992). Power calculations for general linear multivariate models including repeated measures applications. Journal of the American Statistical Association, 87(420), 1209-1226.

Müller-Hartmann, A., \& Schocker-von-Ditfurth, M. (2011). Teaching English: Task-supported language learning. Berlin: Schöningh.

Novak, J. D. (1990). Concept mapping: A useful tool for science education. Journal of Research in Science Teaching, 27(10), 937-949.

Novak, J. D., \& Cañas, A. J. (2008). The theory underlying concept maps and how to construct and use them. Technical Report Institute for Human and Machine Cognition, CmapTools, Pensacola Fl.

Ökcü, E. D. (2014). Effects of task-based instruction on reading comprehension of EFL learners. International Journal of English Language Teaching, 3(2), 23-37.

Olson, D. R. (2007). Jerome Bruner: The cognitive revolution in educational theory. New York: Continuum.

Palinscar, A. S., \& Brown, A. L. (1984). Reciprocal teaching of comprehension, fostering and monitoring activities. Cognition and Instruction, 1, 117-175.

Peterßen, W. (2009). Kleines Methoden-Lexikon. München: Oldenbourg.

Petrina, S. (2006). Advanced teaching methods for the technology classroom. New York: Information Science Publishing.

Petty, G. (2009). Teaching today: a practical guide. Cheltenham: Nelson Thornes.

Scrivener, J. (2011). Learning teaching. The essential guide to English language teaching. London: Macmillan.

Seyedi, S. H., \& Farahani, A. A. K. (2014). The application of task-based writing and traditional writing on the development of reading comprehension of EFL advanced Iranian learners. International Journal of English Language Education, 2(1), 225-240. 


\section{Macrothink}

Sims-Knight, J. E., \& Upchurch, R. L. (1993) Teaching object-oriented design without programming: a progress report. Computer Science Education, 4(1), 135-156.

Tennyson, R., Schott, F., Seel, N., \& Dijkstra, S. (1997). Instructional design: International perspective: Theory, research, and models. (Vol. 1). Mahwah, NJ: Lawrence Erlbaum Associates.

Thaler, E. (2012). Englisch unterrichten: Grundlagen - Kompetenzen - Methoden. Berlin: Cornelsen.

Thaler, E. (2008). MAFF (Münchener Arbeiten zur Fremdsprache-Forschung). Berlin: Langenscheidt.

The Center for Teaching and Learning (2018). 150 teaching methods. Retrieved from http://teaching.uncc.edu/learning-resources/articles-books/best-practice/instructional-methods /150-teaching-methods (January, 10, 2016)

Timm, J.-G. (2005). Englisch lernen und lehren. Berlin. Cornelsen.

Tomlinson, C. A. (1999). The differentiated classroom: Responding to the need of all learners. Alexandria, VA: Association for Supervision and Curriculum Development.

Vaux, A., \& Briggs, C. S. (2005). Conducting mail and Internet surveys. In F. T. L. Leong, \& J. T. Austin, The psychology research handbook (pp. 186-209). Thousand Oaks, CA: Sage.

Wankel, C., \& Blessinger, P. (2012). Increasing student engagement and retention using online learning activities: Wikis, blogs and webquests. London: Emerald Group.

Ward, J. H. (1963). Hierarchical groupings to optimize an objective function. Journal of the American Statistical Association 58, 236-244

Wiechmann, J. (Ed.) (2011). Zwölf Unterrichtsmethoden. Weinheim: Beltz.

Winer, B. J., Brown, D. R., \& Michels, K. M. (1991). Statistical principles in experimental design. Boston, MA: McGraw-Hill.

Zendler, A., Seitz, C., \& Klaudt, D. (2016). Booklet III: Instructional methods for the English classroom. Berlin: epubli. 


\section{Appendix}

\section{Appendix 1. Instructional methods}

1 Case study. Case study (Davis, 2009) is an instructional method aimed at the development of independent problem-solving skills by including realistic cases and tasks in the instruction.

2 Computer simulation. Computer simulation (Aldrich, 2009) comprises the application of simulation software for the virtual solution of (time-related) problems.

3 Concept mapping. Concept mapping (Novak, 1990; Novak \& Cañas, 2008) is an instructional method for the structuring and depiction of concepts and their relationships.

4 Direct instruction. Direct instruction (Petty, 2009) is an instructional method with a central focus on the teacher. The teacher assumes the central role in directing the activities associated with the instruction and does not relinquish this role until the end of the learning process.

5 Discovery learning. Discovery learning (Petty, 2009) is an instructional method with a central focus on the pupils in which learning recommendations are the focal point in order to motivate self-learning.

6 Experiment. The experiment (Abell \& Lederman, 2007) as an instructional method serves in the conveyance of knowledge by making the effects of dependent variables observable through the planned variation of independent variables.

7 Jigsaw. The jigsaw method (Aronson, 1978) is a cooperative learning instructional method in which pupils instruct their co-pupils by becoming experts on a particular topic and taking on instructional activities.

8 Learning (at) stations. Learning (at) stations (Tomlinson, 1999) is a student-oriented instructional method in which pupils learn independently on the basis of prepared materials provided at workstations.

9 Learning by teaching. Learning by teaching (Gartner et al., 1971; Biswas et al., 2005) is an activity-oriented instructional method in which pupils learn by teaching one another.

10 Learning tasks. Learning tasks (Flewelling \& Higginson, 2003) as an instructional method serve in initiating and guiding learning and thinking processes.

11 Leittext method. The Leittext method (Höpfner et al., 1997) is an instructional method with which learners are guided in regard to content and methodology in such a manner that they can acquire knowledge with prepared materials.

12 Models method. The models method (Abell \& Lederman, 2007) is an instructional method comprised of forming models and applying models in a particular field.

13 Portfolio method. The portfolio method (Davis, 2009) is an instructional method which allows the persons learning to be aware of their own learning progress (with the help of a folder) in which they individually develop a conscientious approach to the quality and to their responsibility for their own learning process. 
14 Presentation. Presentation (Petty, 2009) as an instructional method serves as verification that learners can gather, process and present information in an organized manner.

15 Problem-based learning. Problem-based learning (Donath, 2006; Abell \& Lederman, 2007; Moust, Bouhuijs, \& Schmidt, 2007) is an instructional method enabling learners to acquire skills in the resolution of an exemplary problem which can then be transferred to other applicable problem areas.

16 Programmed instruction. Programmed instruction is an instructional method (Canton, 2007) focusing on individualized material for the person learning to study on their own.

17 Project work. The project work method (Branom, 2008) is an activities-oriented instructional method allowing learners to work on a defined objective in an organized, independent manner.

18 Reciprocal teaching. Reciprocal teaching (Palinscar \& Brown, 1984) is a dialogical instructional method between teachers and learners which serves as a tool in grasping the meaning of texts. There are few teaching examples cited in the relevant literature applying reciprocal teaching as an instructional method. Sims-Knight and Upchurch (1993) documented a teaching unit on object-oriented design.

19 Role-play. The role-play method (Petty, 2009) is an activities-oriented instructional method designed to promote the understanding of simple and complex activity sequences related to technology.

20 Web quest. Web quest (Wankel \& Blessinger, 2012) is a research-oriented instructional method which includes Internet-based services (e.g. Wikipedia, portals, literature databases) and Internet technologies (e.g. E-Learning platforms, Cloud computing, E-communication) in the learning process.

\section{Appendix 2. Knowledge Processes}

1 Build. Acquiring knowledge, new practical and cognitive abilities as well as attitudes.

2 Process. Establishing, deepening, structuring and connecting what has been learned.

3 Apply. Using what has been learned in new tasks corresponding with the framework conditions of the learning situation.

4 Transfer. Using what has been learned in new situations in which the framework conditions differ from those of the learning situation.

5 Assess. Classifying what has been learned in regard to its usefulness, scope, benefits and limits.

6 Integrate. Integrating what has been learned outside of the actual learning situation in connection with one's own knowledge. 


\section{IIMacrothink}

\section{Appendix 3. Questionnaire}

Please evaluate:

The act of learning through instructional methods in English classroom.

Please rate each cell on a scale of 0 to 5 (only whole numbers.

It is important that you provide 6 ratings per row.

$\begin{array}{llllllll}\text { not significant } & 0 & 1 & 2 & 3 & 4 & 5 & \text { very significar }\end{array}$

\begin{tabular}{|c|c|c|c|c|c|c|c|}
\hline & \begin{tabular}{|l} 
Knowledge processes \\
(Explanations, see \\
Booklet)
\end{tabular} & 을 & 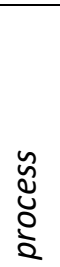 & $\frac{2}{\frac{2}{2}}$ & 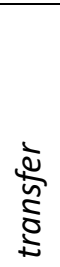 & 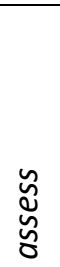 & 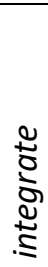 \\
\hline 1 & Case studv & & & & & & \\
\hline 2 & Comnuter simulation & & & & & & \\
\hline 3 & Concent mannina & & & & & & \\
\hline 4 & Direct Instruction & & & & & & \\
\hline 5 & Discoverv learnina & & & & & & \\
\hline 6 & Exneriment & & & & & & \\
\hline 7 & Jiasaw method & & & & & & \\
\hline 8 & Learnina (at) stations & & & & & & \\
\hline 9 & Learnina bv teachina & & & & & & \\
\hline 10 & Learnina tasks & & & & & & \\
\hline 11 & Leittext method & & & & & & \\
\hline 12 & Models method & & & & & & \\
\hline 13 & Portfolio method & & & & & & \\
\hline 14 & Presentation & & & & & & \\
\hline 15 & Problem-based learnina & & & & & & \\
\hline 16 & Proarammed instruction & & & & & & \\
\hline 17 & Proiect work & & & & & & \\
\hline 18 & Recinrocal teachina & & & & & & \\
\hline 19 & Role-nlav & & & & & & \\
\hline 20 & Web auest & & & & & & \\
\hline
\end{tabular}




\section{Appendix 4. Data}

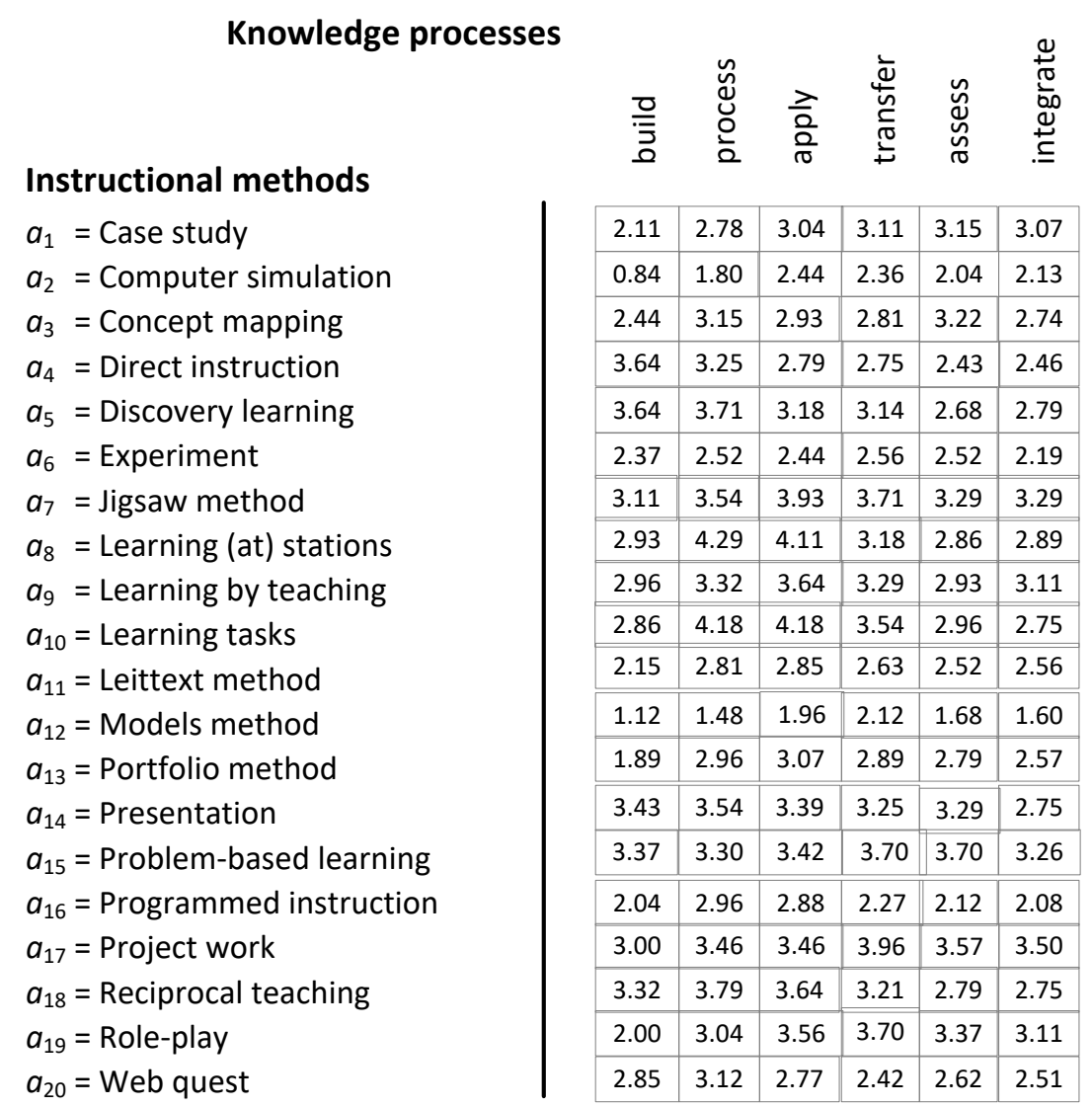

Figure A-1. Means of instructional methods with respect to knowledge processes $(N=28)$

\section{Copyright Disclaimer}

Copyright for this article is retained by the author(s), with first publication rights granted to the journal.

This is an open-access article distributed under the terms and conditions of the Creative Commons Attribution license (http://creativecommons.org/licenses/by/3.0/). 